\title{
テラビット超大容量光スイッチ
}

逸見 直也*, 高橋 成五 ${ }^{*}$

\section{Beyond Tera Bit per Second Capacity Ultra-Large Scale Optical Switch Fabric Technology}

\author{
Naoya HENMI* and Seigo TAKAHASHI*
}

*日本電気株式会社C\&Cメデイア研究所（テ216-8555 神奈川県川崎市宮前区宮崎4-1-1）

*C\&C Media Research Laboratories, NEC Corporation (4-1-1 Miyazaki, Miyamae-ku, Kawasaki-shi, Kanagawa 216-8555)

\section{1. はじめに}

現在北米では，インターネットを中心としたマルチメデ イアサービスの発展により通信ネットワークに爆発的な容 量拡大が必要とされており，今後このような容量拡大の動 きは世界各地に波及すると考えられる。このような容量拡 大に応える技術として，北米を中心に波長多重技術を用い た伝送容量の拡大が盛んに進められており，研究レベルで はすでに各所でテラビットを越える容量の伝送実験が行わ れている”。一方，ネットワークを構成するための基本要 素であり, 主にネットワーク内での経済的な多重化, 経路 設定変更，ネットワーク状態の把握，ネットワーク障害時 の自動復旧等の機能を果たすスイッチング技術に関して も，容量の拡大が伝送技術と並行して行われることが必要 である。しかし，このスイッチング容量の拡大に関しては, 従来から用いられている電気スイッチ技術の延長では超 $\mathrm{Tb} / \mathrm{s}$ 級のスイッチを実現することが困難であることが判 明しつつあるものの，ブレークスルー技術はいまだ確立さ れていない。

我々は，現在この超大容量スイッチ技術を実現するブレ 一クスルー技術として光技術，特に波長多重技術を利用し たテラビット超大容量光スイッチの研究・開発を行ってい る。本稿では, まず現在, 我々が検討している半導体アン プゲートスイッチを基本要素とした波長多重／空間多重超 大容量光スイッチ技術を紹介する。最後に，この技術を実 用化するにあたり光実装技術に期待する項目をまとめる。

\section{2. 波長多重/空間多重超大容量光スイッチ}

本節では，まず将来の通信ネットワークに必要となる超 大容量光スイッチへの要求項目をまとめ，次にこれを実現 する手段である我々の提案する波長多重／空間多重光スイ ッチについて述べる。最後に我々の提案する光スイッチの 利点をまとめる。

2.1 超大容量光スイッチへの要求項目

先に述べたように将来の超 $\mathrm{Tb} / \mathrm{s}$ 容量通信ネットワーク
用スイッチ技術には，一般的に以下の要求項目の実現が必 要である。

1) スイッチサイズとして，数 $100 \times$ 数 100 以上の大規模 スイッチ

2）完全非閉塞性（場合によっては，マルチキャスト機 能も兼備）

3) 数nsecでの高速切り替え機能（将来のセル／パケッ 卜単位での切り替えあるいは多重化応用を考えた場合）

等，である。1)の条件は，将来の数十波-100波以上の波 長多重ネットワーク内において，波長ごとの切り替えを行 う場合に不可欠な条件であり，2)は，クロスコネクト等， 従来のノード技術が必要とする条件，3)は，将来デー夕サ 一ビスの多重化，グルーミングを行うルータやA T Mスイ ッチへの応用を考えた場合，つまりパケット／セル交換用 光スイッチに必要となる条件である。

要求項目3)は，光波長ごとの経路張り替えを行う光ク口 スコネクトを実現する際には不必要な条件である。しかし， 将来のルータやATMスイッチへの光スイッチ応用拡大を 考慮して（光スイッチ素子自体の応用分野の拡大による量 産化，ひいては低コスト化を期待するため), 我々は1)3)のすべての条件を満たす光スイッチ構成を中心に超大容 量光スイッチの研究・開発を進めている。

\section{2 要求項目を満足する光スイッチ構成}

以下では，前節で述べた要求条件を満たす光スイッチ構 成に関して検討する。まず要求条件を満足するために光ス イッチ素子に要求される条件を抽出して光スイッチ素子を 決定した後に，光スイッチの構成方法（アーキテクチャ） を決定する。

前節で述べた要求条件1)，3)のスイッチサイズ（光増幅 機能，低クロストーク特性が不可欠）と高速切り替え特性 の必要性から, 光スイッチ素子には光増幅特性, $-40 \mathrm{~dB}$ 以上の低クロストーク特性，ナノ秒オーダの高速スイッチ ング特性を有する半導体光アンプゲートスイッチ素子 （SOAG）が適すると考える。この半導体アンプゲートス イッチは, 将来の光集積化・量産化に優れ，多種多様な応 
用用途が考えられるため, 光スイッチ技術として最も期待 できる光半導体素子である。

次にこの半導体光アンプゲートを用いた光スイッチの構 成法を検討する。半導体光アンプゲートを用いて単純な大 規模完全非閉塞空間光スイッチを構成する場合，本素子は シャッ夕機能のみを有するため, 分配選択型光スイッチを 構成する必要がある。このような光スイッチ構成を実現す るためには，以下の点が大きな課題である。

1) 膨大な数のSOAG（光スイッチ素子）を必要とする 点 $\left[(\text { ポート数 })^{2}\right.$ のオーダのエレメント数 $]$

2) 光スイッチ内での合分波損失に起因した信号対雑音 $(\mathrm{S} / \mathrm{N}$ 比) 劣化

3）光スイッチ素子をメッシュ状に接続するため, 複雑 な光ファイバ配線実装技術を必要とする点

これらの問題を解決するために，我々は，光技術に独特 な（電気技術にはない）波長多重技術を利用して大規模光 スイッチを構成するのに適した波長／空間光スイッチ構成 方法を提案している。

我々の提案する光スイッチの構成をFig. 1 に示す2。こ の光スイッチは, 波長多重群で群交換する空間スイッチ部 分と, 波長多重された信号から 1 波長の信号を取り出す波 長セレク夕の 2 段スイッチ構成を取る。

以下, 簡単に提案する光スイッチの構成および動作を説 明する。入力ポートはそれぞれあらかじめ特定な波長に割 り当てられ, 複数の異なる波長を割り当てられた入力ポー 卜の出力が波長多重化されて波長群を構成する。それぞれ の波長群は, エルビウムドープ光ファイバ増幅器 (EDFA) を用いて波長一括増幅され，各出力ポートへ分配される。 分配された波長群は，以下に示す波長／空間光セレク夕に より選択され出力される。Fig. 2 に波長／空間光セレクタ の構成を示す。図中, 初段SOAG群は, 空間選択セレタタ にあたり，出力ポートでどの波長群を取り出すかを選択す る光スイッチである。この初段SOAGで選択された波長群 は, 波長ルー夕（AWG）を利用して波長分離され, 次段

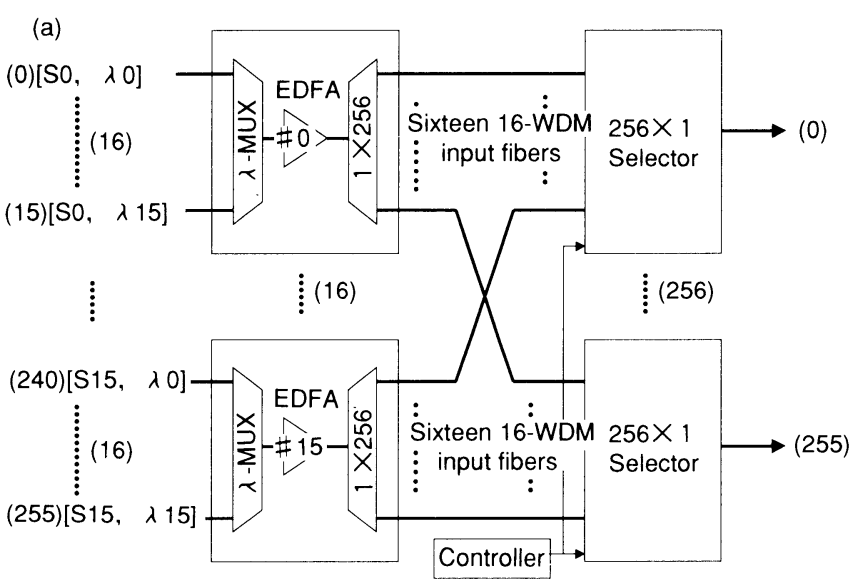

Fig.1 WD (Wavelength division) /SD (Space division) optical switch fabric configuration (256 ports $\times 256$ ports)

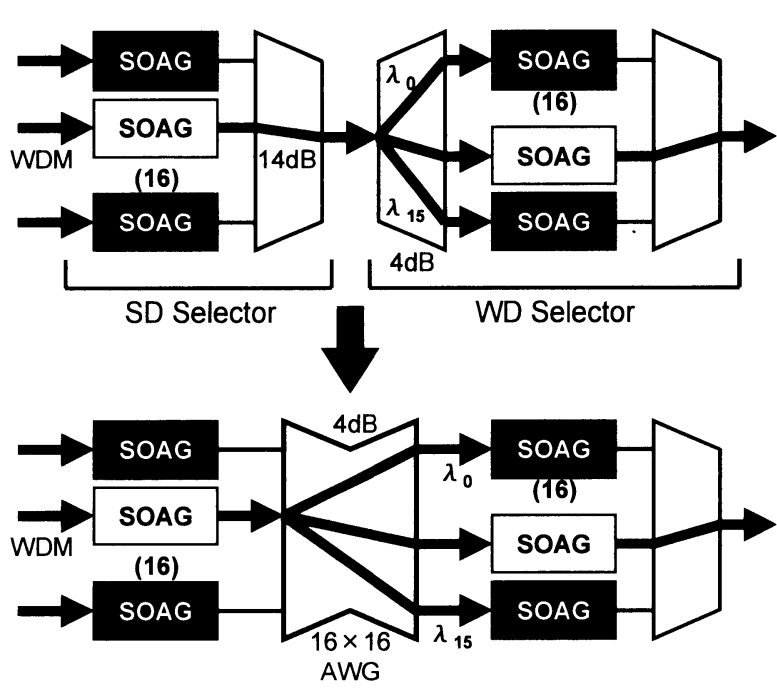

Fig.2 WD/SD optical selector configuration

SOAG群によって 1 波長信号が選択される。この空間選択 セレクタと波長選択セレクタの 2 段構成のセレクタによ り，出力側は，いかなる入力信号光をも選択できることと なり, 本光スイッチはマルチキャスト可能な完全非閉塞ス イッチとなっていることがわかる〔要求項目2)〕。

2. 3 提案する波長多重/空間多重光スイッチの利点

本来, 波長多重技術を用いずに空間スイッチのみで光セ レク夕を構成すると, 各出力ポートに入力ポート数分の SOAGが必要となる。一方, 本構成では光技術独特な波長 群交換方式を用いて空間／波長の 2 段光セレク夕構成を取 り, SOAG数を大幅に削減している。Fig. 3 にスイッチ規 模をパラメータとしたときのSOAG数と波長多重数との関 倸を示した。例えば，256×256のスイッチ規模を考えた場 合, 波長多重数16のときSOAG数が最小となり, 単純な空 間スイッチを構成した場合の $1 / 8$ に削減される。このため, 後述する $256 \times 256$ の光スイッチデモンストレー夕は，16波 長多重技術を用いている。

次に, 光スイッチ内に拀ける光信号損失に関して考える。

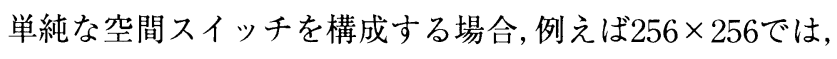
光送信器から光受信器までに $(1 / 256)^{2}$ の光損失を生じる (256出力ポートへ分配損と, 256個のセレクタから出力さ

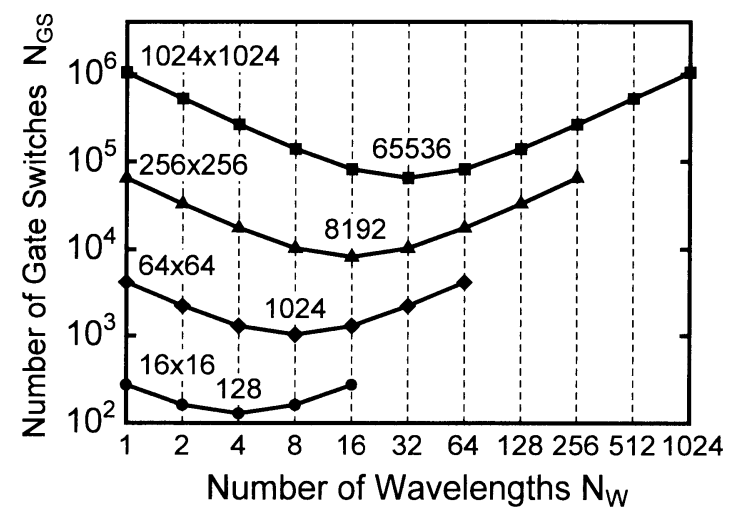

Fig.3 Relationship between required SOAG number and employed wavelength number 
れた信号を合波する合波損)。一方，我々の提案する波長 多重/空間多重光スイッチでは，波長合分波損を零とする と, $(1 / 256)^{2} \times$ (波長多重数) と波長多重数分だけ損失を 低隇できる〔256出力ポートへ分配損と，(256/(波長数)) 個の次段SOAG群から出力された信号を合波する合波損】。 ここで, 波長多重数分の損失が低減されているのは, 波長 多重/空間多重光セレタタ内に波長ルータを導入し, 従来 空間的合分波の際に生じた分波損を削減したためである (Fig. 2 参照)。

また，実装面から見ると，波長多重した信号光を分配す るため, 次節で述べるように光セレタタを 1 パッケージに 実装すると，

a. 光セレクタへの光ファイバ入力数を（1／波長多重 数)に大幅に削減できる

b. 波長多重した信号光を一括増幅できるため分配損の 補償に用いる光増幅器の数が削減できる

等,の大きな利点がある。

\section{3. 超大容量波長多重/空間多重光スイッチデモンス トレータ}

本節では, まず我々の提案する波長多重 /空間多重光ス イッチに基本光スイッチエレメントとして用いる半導体ア ンプゲートスイッチ素子に関して述べ, 次に実際に半導体 アンプゲートスイッチ素子を用いて試作した $10 \mathrm{~Gb} / \mathrm{s} /$ ポー ト, $256 \times 256$ までポート数拡大可能な光スイッチの部分試 作デモンストレータについて述べる。

\section{1 半導体アンプゲートスイッチ素子}

Fig. 4 に, 今回光スイッチデモンストレータを試作する にあたって新たに開発した半導体光アンプゲート(SOAG) モジュール写真を示す。光スイッチの装置化を進めるため には，基板上での実装面積削減のためSOAGモジュールは 小型で，(我々の提案する構成方法に適した）アレイ実装 する必要がある。そこで今回我々は, モジュール形状を細 長化し，アレイ実装に適した半導体アンプゲートモジュー ルの開発を行った（体積比で比較すると $1 / 4 ） 。$

Fig. 5 に, 今回開発した半導体アンプゲートスイッチモ

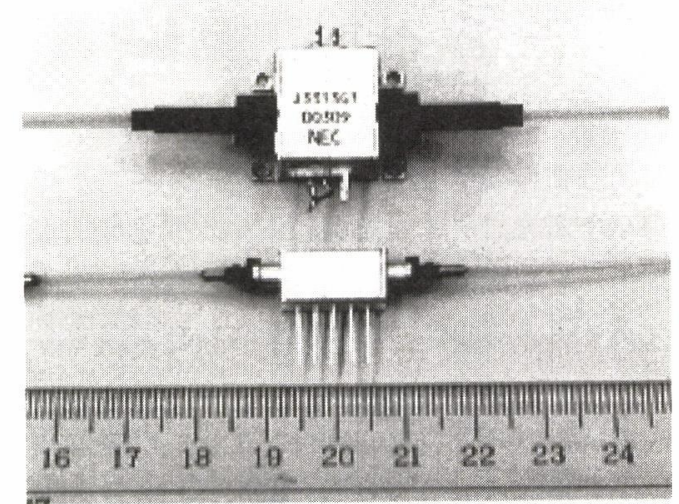

Fig.4 Semiconductor amplifier gate module
ジュールの特性をまとめる。Fig. 5 (a)は, ゲイン対出力光 強度の関係, Fig. 5 (b)は, 応答速度測定結果, Fig. 5 (c)は, 光スイッチとしてのオンオフ比特性を示している。どの特 性においても，先に述べた大規模光スイッチを構成するた めに必要な所要を満たしていることが確認された。

\section{3. $22.56 \mathrm{~Tb} / \mathrm{s}$ 超大容量波長多重/空間多重光スイッチ の部分試作}

前節で述べた半導体アンプゲートスイッチモジュールを 基本光スイッチエレメントとして，10Gb/s/ポート， $256 \times 256$ 波長/空間多重光スイッチ $(2.56 \mathrm{~Tb} / \mathrm{s}$ 容量 $)$ の分 配部と 2 波長多重空間多重光セレタタ試作を行った。 Fig. 6 に16波長多重技術を適用した今回試作機の写真を示 す3)。本試作機は, Hi-PAS規格に準拠したプリント配線板 $\left(320 \times 280 \mathrm{~mm}^{2}\right)$ 上に光部品, 電気部品を実装し, 光信号 入出力およびスイッチ制御電気信号の接続はバックボード を介して行った。また, 架内に強制空冷を施し, 電気回路

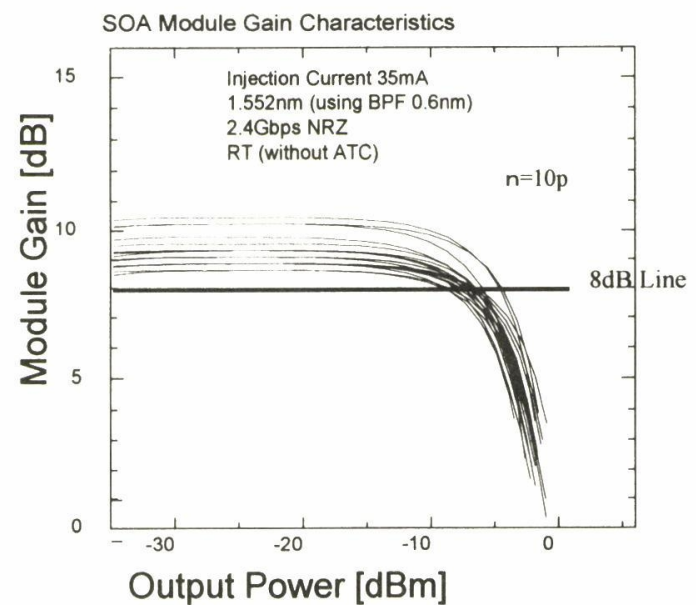

Fig.5 (a) SOAG module gain vs. output power

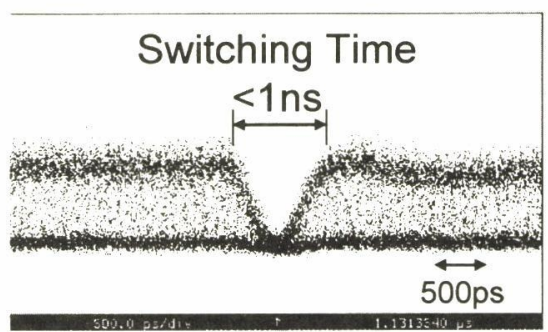

Fig.5 (b) SOAG module switching speed response

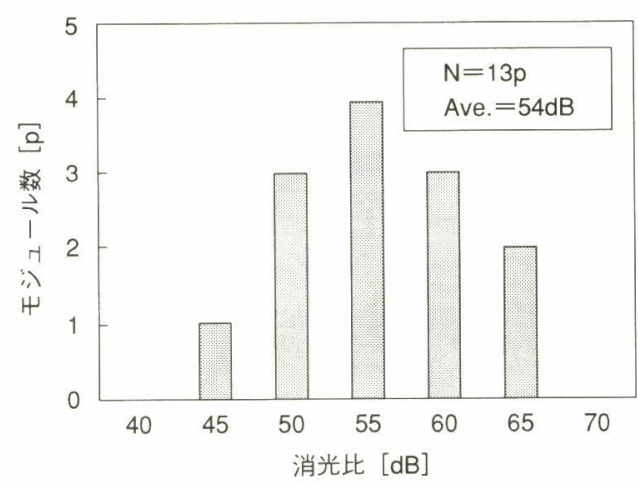

Fig.5 (c) On/off ratio distribution 


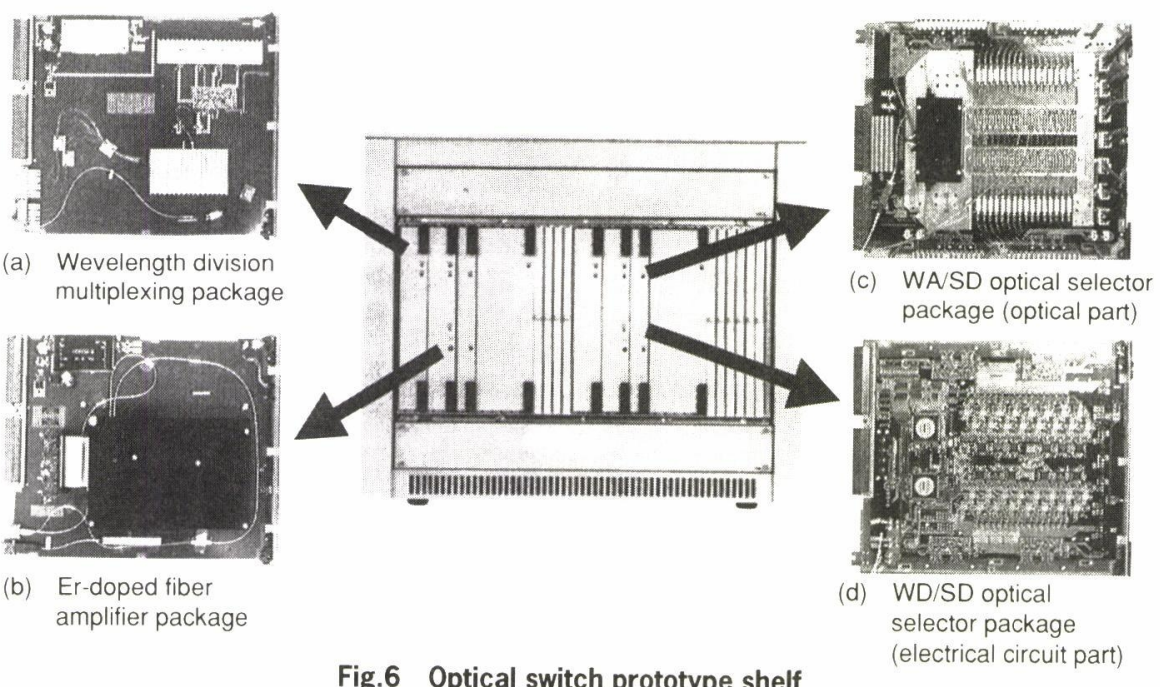

および光素子から発生する熱を排熱した。

図中に今回試作した光スイッチの構成とパッケージ分割 の対応を示した。波長多重パッケージをFig.6 (a)に， EDFAパッケージをFig. 6 (b)に，最も高密度の光実装を必 要とする波長多重/空間多重光セレクタパッケージをFig. 6 (c)に示した。波長/空間光セレクタパッヶージは, 前面 に小型SOAGモジュール32個をアレイ状（16個アレイを2 列）に実装し4，これらを細線光ファイバで接続している。 また，裹面にはSOAGを制御する光スイッチ制御回路， SOAG駆動回路を実装している。

今回試作した各パッケージの大きさから見積もると， 2.56Tbpsスループット光スイッチ全体で約 9 架（36ユ二 ット)になる。これは単純な空間型光スイッチと比較して, 体積比 $1 / 8$ であり, 将来的に光高密度実装技術が確立すれ ば，超 $\mathrm{Tb} / \mathrm{s}$ 級光スイッチを 1 架で構成できる技術へ展開 できるものと期待する。

\section{3 開発した超大容量光スイッチの評価}

次に試作機特性評価を, 各経路10Gbpsにおける符号誤 り率特性, 経路間のスイッチ切り替え時間等で評価した。 光送信器光源には, $1546.1 \mathrm{~nm}(\lambda 0)$ から $1558.2 \mathrm{~nm}(\lambda 15)$ までの $0.8 \mathrm{~nm}$ 間隔 16 個のDFB-LDを用い, これらの光波長信号を 波長多重した後, 光強度変調器を用いて一括変調を行い, 擬似的な波長多重信号源とした。变調信号はパルスパ夕 ンジェネレータ (PPG) から出力される10Gbps, NRZ, $2^{23}-10$ 疑似ランダムパタンである。変調した光信号は, 今 回開発したEDFAパッケージで波長一括増幅された後, 16 分岐光カップラを 2 段縦続接続した疑似256分岐器へ導入 される。後段の16分岐出力は, それぞれ長さの異なる光フ アイバを用いて信号位相相関関係を除去した後に今回試作 した256：1波長多重／空間多重光セレクタ（SEL PKG） に入力した。また, 受信器は, EDFA光前置増幅器（前 述の光送信器光源のすべてを透過する半值幅 $20 \mathrm{~nm}$ の光バ ンドパスフィルタを内蔵）とPIN光受信器で構成した。

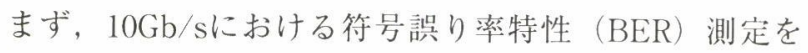

通じて, $256 \times 256$ 光スイッチのクロストークによる信号対 雑音比および波形劣化の評価を行った。すべての波長に対 してBER=10-11以下の安定動作を確認できた。この結果か ら, 光スイッチ通過した信号に大きな劣化がないことが確 認できた。

次に, SEL PKGの切り替え動作特性の評価を行い, すべ てのSOAGが 1 nsec以下で切り替え動作可能であることを 確認した。また，全SOAGの切り替えスキュー測定した結 果, 切り替えスキューを $1 \mathrm{nsec}$ 以下に抑圧できることも確 認した。この結果から, 光スイッチの切り替えガードタイ

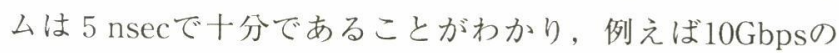
ATM七ルを切り替える応用を考えた場合にも，スイッチ ングのために無効となる帯域は10\%以下に抑压できること が示された。

\section{4. まとめ, 今後の期待}

将来の大容量通信ネットワークの実現に不可欠な超大容 量スイッ千技術と, その実現方法として我々が提案してい る波長多重 空間多重光スイッチ技術について述べた。ま た, 実際に提案している光スイッチの部分試作を行い，良 好な特性が得られたことも示した。提案した波長多重／空 間多重スイッチ技術を用いることで，光スイッチ実装をか なり簡易化したものの, 現状の光モジュール化技術, 光実 装技術では, 実装規模がかなり大きいこと, 接続する配線 技術も複雑となることがわかっている。

今後, キーコンポーネントである半導体アンプゲート素 子およびその他の機能素子との集積化や, 光コンポーネン 卜間を接続する光ファイバ配線のモールド化等, 光モジュ 一ル化技術, 光素子集積化技術, 光配線技術が発展し, 超 大容量光スイッチを小規模に実装できる技術開発展開を期 待したい。

素子の集積化に関して考えると, すべての機能素子を集 積するべきではないと思う。電気実装のアナロジから考え れば, ICと配線ボードというように, 機能素子の集積し 
た電気ICを配線で接続する技術が使われている。光技術 では，いまだ光IC技術が立ち上がっていない状況である から, かなり単純な光IC（例えばアレイデバイス）から 立ち上げ，将来的にパッシブデバイスとの集積化（例えば 波長ルータとの集積化）へと展開するのが望ましいと考え る。最終的な光IC集積度ターゲットに関しては, 光デバ イスの温度特性, 信頼性, 歩留まり等と大いに関係してお り,これらの観点から光デバイス専門家間でのご討論を期 待したい。

また，でき上がった光デバイスを接続する技術に関して 言えば，現状では光デバイスの性能を十分に発揮すること に特化した技術展開がなされている。しかしながら将来的 には, 特に接続簡便性, 低損失性, 製造容易性等様々な要 求項目がある。特性のみから考えれば, 現状, 単純に光フ アイバ接続するのが最も優れている。ぜひこれを打破する 技術展開を，いろいろな観点に精通した実装技術の専門家 の方々にお願いしたい。

これらの技術展開を通じて, 現状電気技術で行われてい るかなり困難なことを, 光技術で簡単に置き換えられる技 術に確立し, 最終的には光産業全体が大きく発展して行く ことを期待する。

(1999.6.7-受理１999.7.16-再受理）

\section{文献}

1) Y.Yano et. al. : “2.6 Terabit/s WDM Transmission Experiments using Optical Duobinary Coding”, ECOC’96, post-deadline paper, ThB3.1, 1996

2) S.Araki et al. : “A $2.56 \mathrm{~Tb} / \mathrm{s}$ Throughput Packet/CellBased Optical Switch-Fabric Demonstrator”, ECOC'98, post-deadline paper, pp.127-129, 1998

3) 高橋成五, 他 : “2.56Tbpsまで拡張可能な超大容量光パケッ トスイッチ”，信学技報，PS98-60, pp.31-35，1998-12
4) 堂前 巧, 他：“大規模光スイッチ用小型SOAゲートモジ ュール”，信学会1998年ソサイエティ大会，C-3-101， 1998

\section{用語解説}

完全非閉塞：スイッチの出力側ポートが空いている場合に, いかなる場合においてもこの空き出力ポートへの経路が存 在するスイッチの特性。

マルチキャスト：入力された信号を, 複数の出力ポートに出 力する機能。

グルーミング：つなぎ先，あるいはサービスクラス等で種別 して束ねる機能。

ATMスイッチ：データサービス等のマルチメディアサービス を行うために，セルと呼ばれる固定長のパケット単位でス イッチする装置。

波長ルータ：入力された波長多重信号を，波長ごとに異なる 出力ポートへ波長分離して出力する素子。また異なる入力 ポートから入力された波長多重信号を入力ポートに依存し て異なる出力ポートに出力する機能も併せ持つ光素子。

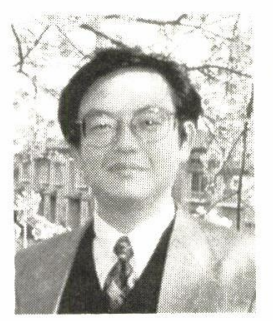

逸見直也(へんみなおや)

昭和36年生まれ。昭和 58 年, 東京大学工学部電 気電子工学科卒業。現在, 日本電気株式会社 C\&Cメディア研究所において, 光通信および 光スイッチング技術応用に従事。

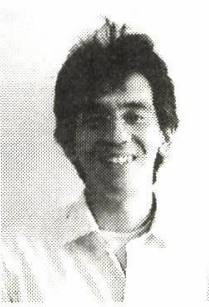

高橋 成五 (たかはし せいご)

昭和 41 年生まれ。平成 4 年, 東京都立大学大学 院修士課程（物理）修了。現在, 日本電気株式 会社C\&Cメディア研究所において, 光交換方 式, 光交換装置および光コンポーネントの研究 開発に従事。 